\title{
Upaya Meningkatkan Kompetensi Guru dalam Mengimplementasikan Pendekatan Saintifik pada Pembelajaran di Kelas Melalui Supervisi Klinis
}

\author{
Ahmad Fathullah \\ Kantor Wilayah Kementerian Agama Kota Serang, Provinsi Banten \\ Email: abi.zahwa1974@gmail.com
}

\begin{abstract}
Abstrak
Kurikulum 2013 menuntut guru untuk melakukan perubahan mindset dan pola pembelajarannya. Untuk itu, pelatihan dan bimtek pun banyak diselenggarakan dengan menghabiskan biaya yang tidak sedikit. Tetapi sangat disayngkan, umumnya mereka masih berada pada posisi 'comfort zone' meski sudah bersertifikat pendidik profesional. Pendekatan saintifik adalah salah satu 'icon' pada standar prosesnya yang menuntut guru agar bersikap kreatif memfasilitasi pengalaman belajar siswa aktif, tetapi realitanya tidak diterapkan. Guru merasa nyaman dengan pembelajaran monolog atau teacher centered. Alternatif tindakan yang harus segera diberikan adalah melakukan supervisi klinis oleh supervisor. Fokus supervisi klinis adalah perbaikan performmance guru di kelas. Seorang supervisor memberikan bimbingan dan layanan yang bersifat kolegial dan menghindari doktrin atau ketegangan. Prosedur supervisi klinis meliputi pra observasi, observasi kelas dan tindakan balikan. Dari hasil penelitian penulis didapati bahwa kegiatan ini dapat meningkatkan kompetensi guru dalam mengimplementasikan pendekatan saintifik pada pembelajaran hingga $43 \%$, yaitu dari nilai awal performen guru di kelas 41 menjadi 83.
\end{abstract}

Kata kunci: kompetensi guru, pendekatan saintifik, supervisi klinis

\begin{abstract}
Curriculum 2013 requires teachers to change their mindset and learning patterns. For that, so many trainings and technical guidances organized by spending a lot of money. But very But very unfortunate, generally they are still in the position of 'comfort zone' despite being certified professional educators. The scientific approach is one of the 'icons' of the process standard that requires teachers to be creative in facilitating an active student learning experience, but the reality is not applied. The teacher feels comfortable with the monologue or teacher centered learning. The alternative action that
\end{abstract}


should be immediately given is to conduct a clinical supervision by the supervisor. The focus of clinical supervision is improving the performance of teachers in the classroom. A supervisor provides guidance and service that is collegial and avoids doctrine or suspense. Clinical supervision procedures include pre-observation, class observation and reversal. From the results of the study authors found that this activity can increase the competence of teachers in implementing the scientific approach on learning up to $43 \%$, ie from the initial value of teacher performance in class 41 to 83 .

Keywords: clinical supervision, scientific approach, teacher competence

\section{Pendahuluan}

Kurikulum 2013 atau sekarag dikenal dengan sebutan kurikulum nasional merupakan sebuah kurikulum yang saat ini dapat dinyatakan ideal dan dapat diandalkan untuk melakukan revolusi mental SDM bangsa. Implementasi kurikulum 2013 menuntut guru untuk mengawali perubahan mind set dari model lama / konvensional ke arah yang lebih profesional dan lebih baik. Diantara perubahan itu adalah pembelajaran yang sering dilakukan dengan satu arah dirubah menjadi multi arah, dari satu metode dirubah menjadi multi metode, dari satu atau tidak media menjadi multi media. Pembelajaran cenderung pada pengalaman belajar siswa yang aktif, kreatif, dan menyenangkan, tetapi guru bukan diam, melainkan sebagai fasilitotor sehingga pengalaman tersebut dapat dilalui oleh semua peserta didik di dalam kelas.

Dengan demikian, kementerian agama melalui Dirjen Pendidikan Islam mengeluarkan surat edaran nomor SE/DJ.1/PP.00/143/2015 tertanggal 5 januari 2015 tentang implementasi kurikulum 2013 Pendidikan Agama Islam (PAI) pada sekolah. Berdasarkan surat edaran ini, sekolah harus tetap menyelenggarakan kurikulum 2013 khususnya mata pelajaran PAI

Kurikulum ideal yang dibuat standarisasinya oleh pemerintah sering 'bersebrangan' dengan kurikulum aktual di dalam kelas. Perubahan 7 kali kurikulum tidak mampu merubah 'mind set' guru dan aktivitasnya di dalam kelas. Kegiatan workshop dan diklat serta bimtek tentang implementasi kurikulum 2013 telah diselenggaran dalam puluhan anggatan. Tapi umumnya guru masih berada pada posisi 'comfort zone' meski sudah bersertifikat pendidik profesional.

Hasil pemantauan penulis di sekolah binaan, ditemukan $90 \%$ guru masih cenderung dominan mentransfer materi pelajaran sedangkan siswa pasif dan hanya 
menerima apa yang disampaikan guru kepadanya. Setelah 6 bulan pertama penulis bertugas di Kota Serang, ditemukan data bahwa 80\% guru belum menggunakan pendekatan saintifik dalam pembelajarannya. Dari $20 \%$ guru yang menggunakan pendekatan saintifik, sebagian dari merekapun belum berurutan dan sistematis dalam KBMnya. Dari hasil observasi kelas, didapati nilai rata guru dalam standar proses khususnya pada kegiatan pembelajaran hanya mencapai 61 atau kategori "C".

Pada kurikulum 2013 aktivitas siswa lebih dipacu dan dikembangkan lagi. Hal ini merupakan tuntutan permendikbud nomor 103 tahun 2014. Di dalamnya dinyatakan bahwa pada kegiatan inti, guru harus mengembangkan pembelajaran dengan pendekatan saintifik. Pendekatan saintifik meliputi 5 (lima) langkah, yaitu mengamati, menanya, mengeksplorasi/mengenksperimen, mengasosiasi, dan mengonfirmasi. Kesemuanya itu mengacu pada peserta didik sebagai subjeknya. Kebijakan dan konsep ini jelas sangat berbeda dengan kenyataan di kelas.

Permendikbud nomor 103 tahun 2014 memaksa guru agar berlaku sebagai fasilitator yang bertugas bukan mentransfer materi pembelajaran secara langsung kepada siswa, tetapi melalui aneka rekayasa agar siswa sendiri yang dapat menemukan konsep itu. Berdasar pada surat edaran dari Dirjen Pendis, dan keadaan real pada sekolah binaan yang berbanding terbalik, maka penulis menganggap perlu segera dilakukan kegiatan supervisi klinis untuk mengatasi persoalan ini.

Supervisi klinis dianggap paling sesuai untuk mengatasi persoalan di atas. Melalui kegiatan supervisi klinis, guru dipacu untuk menyadari kekurangan dirinya dalam proses pembelajaran. berdasarkan kekurangan yang ada, guru dimotivasi agar dapat memperbaikinya dan terus meningkatkan sikap profesionalnya sebagai guru. Berdasarkan permasalahan tersebut, penulis bermaksud melakukan telaah atau kajian dengan judul "Upaya peningkatan Kompetensi Guru dalam Mengimplementasikan Pendekatan Saintifik pada Pembelajaran di Kelas Melalui Supervisi Klinis".

\section{Hasil dan Diskusi}

\section{Pendekatan Saintifik}

Pendekatan saintifik merupakan salah satu karakteristik dalam kurikulum 2013. Konsep ini menjadi bagian dalam standar proses. Selama perjalanan implementasi kurikulum 2013, standar proses mengalami 3 (tiga) kali perubahan. Tetapi pendekatan saintifik tidak termasuk bagian yang dirubah. Standar proses yang terbaru saat ini masih 
mengacu pada permendikbud nomor 103 tahun 2014. Berdasarkan peraturan tersebut, pendekatan saintifik diartikan sebagai pendekatan berbasis proses keilmuan.

Pendekatan saintifik dapat dikembangkan melalui beberapa strategi seperti discovery learning, project-based learning, problem-based learning, inquiry learning. Di dalamnya terdapat 5 kegiatan atau dikenal denga $5 \mathrm{M}$, yaitu: mengamati, menanya, mengeksplorasi, mengasosiasi, mengomunikasikan.

a. Mengamati; kegiatan yang dilakukan siswa berupa mengamati dengan indra (membaca, mendengar, menyimak, melihat, menonton, dan sebagainya) dengan atau tanpa alat.

b. Menanya; kegiatan yang dilakukan siswa berupa membuat dan mengajukan pertanyaan, tanya jawab, berdiskusi tentang informasi yang belum dipahami, informasi tambahan yang ingin diketahui, atau sebagai klarifikasi.

c. Mengeksplorasi; kegiatan yang dilakukan siswa berupa mengeksplorasi, mencoba, berdiskusi, mendemonstrasikan, meniru bentuk/gerak, melakukan eksperimen, membaca sumber lain selain buku teks, mengumpulkan data dari nara sumber melalui angket, wawancara, dan memodifikasi/ menambahi/ mengem-bangkan.

d. Mengasosiasi; kegiatan yang dilakukan siswa berupa mengolah informasi yang sudah dikumpulkan, menganalisis data dalam bentuk membuat kategori, mengasosiasi atau menghubungkan fenomena/informasi yang terkait dalam rangka menemukan.

e. Mengomunikasikan; kegiatan yang dilakukan siswa berupa menyajikan laporan dalam bentuk bagan, diagram, atau grafik; menyusun laporan tertulis; dan menyajikan laporan meliputi proses, hasil, dan kesimpulan secara lisan.

\section{Supervisi Klinis}

\section{a. Pengertian Supervisi Klinis}

Kata "supervisi" berasal dari bahasa Inggris yaitu supervision yang terdiri dari dua kata; super dan vision. Supervisi dapat diartikan melihat dengan sangat teliti pekerjaan secara keseluruhan. Orang yang melakukan supervisi disebut supervisor. Menurut Ngalim Purwanto yang dikutip dari Qodri et all (2004:26) mengatakan bahwa supervisi adalah suatu aktivitas pembinaan yang direncanakan untuk membantu para guru dan pegawai sekolah lainnya dalam melakukan pekerjaan mereka secara efektif.

Berdasarkan pendapat tersebut dapat kita pahami bahwa supervisi adalah kegiatan yang terencana dalam rangka membina guru atau pegawai lainnya yang ada di sekolah agar mereka dapat bekerja sesuai tugas dan fungsinya dengan baik dan 
benar. Seseorang yang akan melakukan supervisi harus sudah memiliki perencanaan yang matang sebelum melakukan kegiatan.

Kata "klinis" memiliki konotasi mengobati. Secara bahasa, supervisi klinis menjadikan guru sebagai pasien yang datang kepada supervisor untuk diobati karena memiliki keluhan atau permasalahan dalam melaksanakan "TUSI-nya' sebagai guru. la menyampaikan keluhannya, kemudian supervisor mengobservasi atau memberikan beberapa pertanyaan yang berkaitan dengan keluhan guru dan diakhiri dengan memberikan obat sesuai diagnosa melalui pertanyaan-pertanyaan yang disampaikan kepada guru dan keluhannya.

Dalam buku "Modul dan Model Pelatihan Pengawas PENDAIS" karangan H. A Qodri et all (2002:102) dinyatakan beberapa pendapat para ahli tentang supervisi klinis. Diantaranya :

a. Acheson dan Gall mengatakan bahwa supervisi klinis adalah proses membantu guru memperkecil ketidaksesuaian (kesenjangan) antara tingkah laku mengajar yang nyata dengan tingkah laku mengajar yang ideal

b. Richard Waller berpendapat bahwa supervisi klinis adalah supervisi yang difokuskan pada perbaikan pengajaran dengan melalui siklus yang sistematis dari tahap perencanaan, pengamatan, dan analisis intelektual yang intensif terhadap penampilan mengajar sebenarnya dengan tujuan untuk mengadakan modifikasi

Dari dua pendapat di atas dapat disimpulkan bahwa inti dari supervisi klinis adalah perbaikan penampilan guru dalam memfasilitasi pemebelajaran di kelas. supervisi ini dilakukan oleh supervisor untuk membantu guru agar dapat mengajar ideal sesuai kurikulum yang telah direncanakan. Di dalamnya terdapat sebuah proses yang sistematis mulai dari perencanaan, pengamatan, dan analisis intelektual yang intensif terhadap penampilan mengajar sebenarnya serta memberikan tindakan supervisi dengan tujuan untuk mengadakan perbaikan dan/atau modifikasi. Pada akhirnya, apa yang dilakukan guru sesuai dengan apa yang direncanakan tanpa ada kesenjangan.

\section{b. Tujuan Supervisi Klinis}

Fokus Supervisi Klinis adalah perbaikan permformence guru di kelas. Sesuai pendapat Acheson dan Gall yang dikutip dari Qodri tujuan Supervisi Klinis adalah:

1) Memberikan gambaran secara objektif kepada guru mengenai penampilan mengajar apa adanya (aktual)

2) Mendiagnosis dan memecahkan permasalahan pembelajaran

3) Membantu guru mengembangkan keterampilan dalam hal strategi pembelajaran yang digunakan 
4) Membantu guru mengembangkan sikap positif dalam pengembangan profesionalitas secara berkesinambung-an (Qodri et all, 2002:102-103).

\section{c. Prinsip-Prinsip Supervisi Klinis}

Ada beberapa prinsip umum yang harus diketahui sebelum supervisor melakukan supervisi model ini. Untuk keberhasil kegiatan supervisi, prinsip-prinsip ini harus dijadikan dasar berpijak dalam pelaksanaannya. Menurut Acheson dan Gall (1992:9) ada tiga prinsip umum yang harus dipegang teguh oleh supervisor dalam pelaksanaan supervisi, yaitu interaktif bukan direktif, demokratis bukan otoritatif, dan berpusat pada guru bukan pada supervisor.

Interaktif dapat diartikan ada interaksi dialogis yang bersifat akrab dan terbuka antara guru dan supervisor pada diskusi sebagai kegiatan balikan pasca observasi kelas. Supervisor tidak memberikan instruksi atau mematahkan pendapat guru, melainkan memberikan layanan bimbingan melalui pertanyaan-pertanyaan yang mengarahkan pada peningkatan keterampilan guru dalam pembalajran sesuai harapan/peraturan dan perundang-undangan.

Demokratis dapat diartikan bebas mengemukakan pendapat. Maksudnya supervisor memberikan kebebasan atau hak kepada guru yang disupervisi untuk mengungkapkan pendapatnya secara terbuka. Tetapi supervisor tetap memiliki kewajiban untuk mengarahkan pendapat dan pandangan guru itu pada konsep dan keterampilan yang benar. Supervisor tidak diperkenankan bersikap memaksakan kehendak atau mematahkan pendapatnya, tetapi ia harus mampu memberikan arahan/gambaran yang meyakinkan guru dengan harapan ia dapat memperbaiki atau meningkatkan kinerja/profesionalismenya dengan suka rela.

Berpusat pada guru berarti maksudnya adalah sasaran supervisi terpusat pada kebutuhan dan aspirasi guru. Guru harus merasakan manfaat dari kegiatan supervisi ini. Untuk itu, kegiatan ini disesuaikan dengan apa yang dibutuhkan guru dalam peningkatan pembelajaran di kelas. Pasca observasi kelas, seorang supervisor segera memberikan umpan balik atau mengajaknya berdiskusi tentang apa yang telah dilakukan. Jika ditunda dalam waktu yang cukup lama, dimungkinkan guru sudah melupakan beberapa kegiatannya sehingga kesulitan memperbaikinya.

\section{d. Prosedur Supervisi Klinis}

Secara garis besar, semua literatur sepakat bahwa prosedur supervisi klinis meliputi tiga tahapan, yaitu tahap pendahuluan (pra observasi), tahap pelaksanaan observasi kelas, dan pertemuan balikan (pasca observasi). Prosedur supervisi klinis 
dapat disebut "siklus". Karena tiga tahap tersebut di atas merupakan suatu proses yang berkelanjutan. Untuk lebih jelas, dapat dilihat pada gambar berikut.

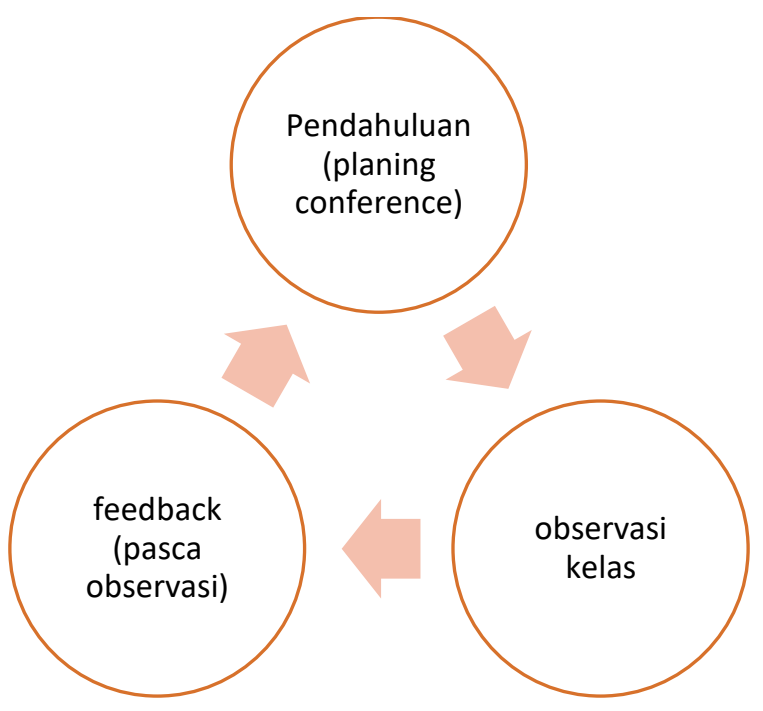

Gambar 1. Siklus Supervisi Klinis

a. Tahap Pendahuluan/Pra Observasi

Tahap pertama dalam supervisi klinis adalah pertemuan pendahuluan atau pembicaraan awal pra observasi kelas. Tahap ini dapat berlangsung beberapa jam sebelum observasi kelas atau sehari sebelumnya. Esensi pada tahap ini menurut Qodri et all (2002:106) adalah "menciptakan suasana yang akrab, terbuka, dan penuh persahabatan, jadi yang terjalin hubungan kolegial dalam suasana kerja sama yang harmonis".

Di samping itu, pada tahap ini dibicarakan rencana keterampilan yang akan diobservasi dan dicatat. Dalam suasana keakraban itu, supervisor membicarakan dengan guru yang disupervisi hingga membuat kesepakatan yang berkaitan dengan:

1) Rencana Pelaksanaan Pembelajaran (RPP) yang akan digunakan; meliputi materi pokok, metode yang digunakan, dan keterlibatan siswa dalam pembelajaran.

2) Fokus observasi di kelas; berkaitan dengan aspek keterampilan apa yang diobservasi, contoh keterampilan guru dalam mengimplementasikan pendekatan saintifik.

3) Teknik supervisor dalam merekam atau mencatat hasil pengamatan. Contoh rubrik observasi kelas atau alat komunikasi seperti kamera.

b. Tahap Observasi Kelas

Tahap kedua adalah melakukan apa yang telah disepakati dalam tahap pendahuluan. Fokus utama dalam tahap ini menurut Qodri et all (2003:66) adalah pemusatan perhatian pada siswa, guru, dan interaksi guru dan siswa. 
Mengingat kajian ini berkaitan dengan implementasi pendekatan saintifik pada pembelajaran, maka fokus utama pada kegiatan observasi kelas adalah :

1) bagaimana seorang guru memfasilitasi siswa melalui kegiatan pengamatan, pertanyaan, eksplorasi, asosiasi, dan konfirmasi.

2) Aktivitas siswa selama kegiatan inti

3) Interaksi guru dan siswa dalam lima kegiatan tersebut di atas.

Untuk lebih detilnya, dapat dilihat dalam instrumen observasi kelas.

\section{c. Tahap Feedback (Pasca Observasi)}

Pada tahap terakhir, supervisor melakukan feedback atau balikan dengan guru yang disupervisi tentang apa yang telah dilakukan di kelas. Kegiatan ini segera dilakukan pasca pembelajaran agar apa yang terjadi saat pembelajaran masih diingat oleh kedua pihak. Sebagaimana telah dibahas pada subbab sebelumnya, kegitan ini dapat dilakukan melalui diskusi atau sharing pendapat dengan suasana akrab.

Diskusi dan atau sharing pendapat pada tahap ini berkaitan dengan pencocokan kegiatan inti pada RPP dengan real yang terjadi di kelas sesuai instrumen observasi. Alat atau instrument observasi banyak sekali macamnya. Menurut penggunaannya yang sering dilakukan adalah "ceklist". Homby A.S. (1974) mengatakan bahwa ceklist adalah suatu daftar yang berisi item-item atau nama-nama yang digunakan untuk mengecek sesuatu. Burhanuddin (1994:335) menambahkan bahwa jenis-jenis ceklist khususnya untuk kepentingan supervisi dibedakan atas dua bentuk, yaitu :

1. Evaluatif chek list, yaitu lembaran observasi yang tersusun dari item-item berupa pernyataan-pernyataan atau pertanyaan yang berstandar dan mempunyai sekala penilaian.

2. Actifity chek list yaitu suatu daftar pertanyaan atau pernyataan-pernyataan yang berhubungan dengan aktifitas yang dilakukan oleh guru atau siswa di dalam kelas, diisi dengan kata "ya" atau "tidak".

Dari dua jenis chek list tersebut, kita bisa mengambil salah satunya atau keduanya. Actifity chek list hanya menyatakan bahwa suatu kegiatan itu dilaksanakan atau tidak, tetapi Evaluatif chek list harus mampu memberikan nilai kualitatif terhadap kegiatan yang sedang dilakukan. Dengan demikian, penulis dapat mengatakan bahwa kedua jenis ini dapat dilakukan atau digabungkan/dikombinasikan dalam sebuah instrumen.

Fokus perhatian pada tiga subjek; guru, siswa, dan interaksi keduanya. Supervisor dan guru melakukan refleksi mulai kegiatan mengamati, menanya, mengeksplorasi, mengasosiasi, dan konfirmasi. 


\section{B. Pembahasan}

\section{Analisis Hasil Penelitian Siklus 1}

\section{a. Hasil Observasi Aktivitas Supervisi Klinis Siklus I}

Penulis memberikan perlakuan dalam bentuk tindakan supervisi klinis kepada 15 guru PAI secara individual. Berdasarkan data yang diperoleh melalui observasi terhadap aktivitas guru selama kegiatan supervisi klinis siklus 1 diketahui bahwa aktivitas guru pendidikan agama Islam dalam kegiatan supervisi klinis pada siklus 1 rata-rata mendapat skor 66,7 dengan kategori "cukup". Kegiatan supervisi klinis terdiri dari 3 tahap, yaitu pendahuluan, observasi, dan balikan. Kondisi guru pada tiap tahap tersebut dapat di dapat dilihat pada tabel berikut.

\begin{tabular}{ccc} 
Tabel 2 Data Aktivitas Guru pada Supervisi Klinis Sik \\
\cline { 2 - 3 } No. & Tahapan & Nilai \\
\hline 1. & Pendahuluan (Pra Observasi) & 68,0 \\
2. & Observasi Kelas & 67,8 \\
3. & Tindakan Balikan/Klinis & 64,2 \\
& Jumlah & 200 \\
& Nilai rata-rata & 66,7 \\
\hline
\end{tabular}

Data tersebut di atas mengambarkan tingkat keberhasilan pelaksanaan kegiatan supervisi klinis yang dilakukan pengawas sekolah terhadap guru pendidikan agama Islam relatif cukup memadai. Hal itu terbukti dari skor yang diperoleh pada tiap tahapan.

Aktivitas guru pada tahap pendahuluan mencapai skor rata-rata dari kegiatan berikut.

a. Akivitas guru dan peneliti dalam membuat kesepakatan implementasi pendekatan saintifik pada pembelajaran

b. Respon guru saat kegiatan pra observasi

C. Suasana kolegial dan akrab saat pra observasi

d. Sikap kerja sama guru dengan supervisor saat kegiatan pra observasi

Dari keempat aktivitas tersebut, poin a yang terendah yaitu mencapai 61,3. Sedangkan yang lainnya secara berurutan mencapai 72, 72, dan 66,7.

Pada tahap observasi kelas, aktivitas gurupun nyaris memiliki skor yang sama dengan tahap pendahuluan, yaitu 67,8. Aktivitas yang dilakukan guru pada saat observasi kelas adalah :

a. Respon awal guru tentang keberadaan peneliti di dalam kelas

b. Keberanian guru dalam pelaksanaan pembelajaran yang diobserva

c. Kerja sama guru dan peneliti saat pemebelajaransi peneliti

d. Kedisiplinan guru saat kegiatan

e. Kreativitas guru dalam mengimplementasikan pendekatan saintifik 
f. Hubungan peneliti/pengawas dan guru di dalam kelas

Dari enam point di atas, aktivitas guru yang terendah berdasarkan observasi adalah poin a, yaitu respon awal guru tentang keberadaan peneliti di dalam kelas dengan nilai 51 , sedangkan yang lainnya secara berurutan $64,66,78,78$, dan 70 .

Pada tahap feedback atau tindakan balikan, aktivitas guru mencapai nilai 64,2. Pada tahap ini, guru melakukan kegiatan berikut :

a. Kesiapan guru dalam kegiatan balikan/tindakan klinis

b. Akivitas guru dalam diskusi/sharing pendapat tentang implementasi pendekatan saintifik pada pembelajaran

C. Respon guru terhadap pertanyaan dan bimbingan pengawas/peneliti

d. Suasana kolegial/akrab antara peneliti dengan guru kelas saat kegiatan feedback

e. Sikap kerja sama guru dengan supervisor saat kegiatan tindakan klinis

f. Guru menyimak penyampain data hasil tes unjuk kerja dan bimbingan yang disampaikan oleh pengawas

g. Keberanian guru menyampaikan pendapat atau tanggapan terhadap pernyataan pengawas

h. Keberanian guru mendemonstrasikan contoh keterampilan mengajar yang baik dan benar

i. Keberanian guru menyampaikan pertanyaan

j. Hubungan guru dan peneliti/pengawas selama tindakan klinis

Dari 10 kegiatan itu, pencapaian terendah guru adalah pada poin e, yaitu 48 . Sementara kegiatan lainnya yag belum mencapai 60 adalah poin $\mathrm{d}, \mathrm{f}$, dan $\mathrm{g}$.

\section{b. Hasil Hasil Tes Unjuk Kerja Kemampuan Guru dalam Mengimplementasikan Pendekatan Saintifik}

Dengan perlakukan pengawas melalui supervisi klinis sebagaimana kondisi tersebut di atas, dapat diperoleh peningkatan kompetensi guru dalam mengimplementasikan pendekatan saintifik pada pembelajaran, jika dibandingkan dengan nilai pra siklus. Nilai tersebut dapat digambarkan dalam tabel berikut. 
Tabel 4.4 Nilai Kompetensi Guru dalam Mengimplementasikan Pendekatan Saintifik

\begin{tabular}{|c|c|c|c|c|c|c|c|c|}
\hline \multirow[b]{2}{*}{ NO. } & \multirow[b]{2}{*}{ Nama Guru } & \multirow[b]{2}{*}{ Sekolah Induk } & \multicolumn{5}{|c|}{ Aspek yang Diamati } & \multirow[b]{2}{*}{ 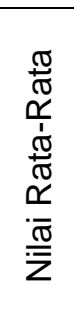 } \\
\hline & & & 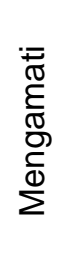 & 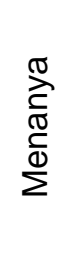 & 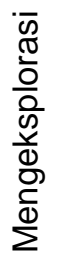 & 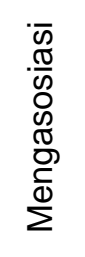 & 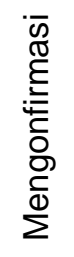 & \\
\hline 1 & MUMU JAJULI & SMPN 3 KOTA SERANG & 90 & 90 & 90 & 70 & 73 & 82,7 \\
\hline 2 & ROHMIAH & SMPN 3 KOTA SERANG & 80 & 80 & 85 & 65 & 70 & 76 \\
\hline 3 & ELA NURLAELA & SMPN 13 KOTA SERANG & 80 & 80 & 85 & 60 & 63 & 73,7 \\
\hline 4 & AFIAH & SMPN 13 KOTA SERANG & 80 & 80 & 80 & 60 & 63 & 72,7 \\
\hline 5 & NANI MULYANI & SMPN 14 KOTA SERANG & 75 & 80 & 85 & 65 & 67 & 74,3 \\
\hline 6 & HARUN & SMPN 14 KOTA SERANG & 75 & 90 & 75 & 65 & 67 & 74,3 \\
\hline 7 & MAFTUHI & SMPN 17 KOTA SERANG & 80 & 80 & 80 & 65 & 67 & 74,3 \\
\hline 8 & $\begin{array}{l}\text { Hj. HIFDATUL } \\
\text { HAYAT } \\
\text { ENI }\end{array}$ & SMPN 17 KOTA SERANG & 75 & 80 & 75 & 60 & 63 & 70,7 \\
\hline 9 & $\begin{array}{l}\text { SUMAERATUL } \\
\text { AENI }\end{array}$ & SMPN 17 KOTA SERANG & 75 & 80 & 75 & 60 & 67 & 71,3 \\
\hline 10 & JULIANA & SMPN 20 KOTA SERANG & 85 & 90 & 85 & 60 & 67 & 77,3 \\
\hline 11 & DEWI MAYASARI & SMPN 20 KOTA SERANG & 75 & 80 & 80 & 60 & 63 & 71,7 \\
\hline 12 & SHAFWATULLAH & SMPIT AL-AZHAR 11 & 85 & 90 & 80 & 60 & 60 & 75 \\
\hline 13 & KHAWASI & SMPIT AL-AZHAR 11 & 85 & 90 & 95 & 60 & 70 & 80 \\
\hline 14 & BUSTOMI & SMPIT AL-IZZAH & 90 & 80 & 85 & 65 & 73 & 78,7 \\
\hline \multirow[t]{2}{*}{15} & IRFAN RF & SMPIT AL-IZZAH & 75 & 80 & 80 & 60 & 67 & 72,3 \\
\hline & \multicolumn{2}{|c|}{ Rata-Rata } & 80 & 83 & 82 & 62,3 & 67 & 75 \\
\hline
\end{tabular}

Berdasarkan tabel di atas, tingkat kemampuan guru pendidikan agama Islam dalam mengimplementasikan pendekatan saintifik pada pembelajaran rata-rata 67,4. Data ini menunjukkan adanya peningkatan kompetensi guru setelah pemberian supervisi klinis siklus 1 .

\section{c. Hasil Angket Guru PAI Terhadap Supervisi Klinis}

Selain data observasi, jurnal, studi dokumentasi, dan penilaian unjuk kerja guru, peneliti juga memperoleh data dari angket yang disebarkan kepada semua guru yang disepervisi untuk memperkuat hasil yang diperoleh dari peneliti sendiri dan juga observer.

Data hasil angket menggambarkan bahwa tingkat apresiasi guru terhadap pelaksanaan kegiatan supervisi klinis dalam bentuk nilai adalah 70,38 atau dibulatkan menjadi 70 . Tahap pendahuluan mencapai nilai 72 , tahap observasi kelas mencapai nilai 70, dan tindakan klinis mencapai nilai 69.

Ketiga nilai tersebut di atas menunjukkan ada korelasi yang signifikan. Dengan demikian, jika perlakuan supervisi klinis semakin baik, maka kompetensi gurupun akan semakin meningkat. 


\section{Penutup}

Supervisi klinis adalah suatu proses membantu guru memperkecil ketidaksesuaian (kesenjangan) antara tingkah laku mengajar yang nyata dengan tingkah laku mengajar yang ideal dalam suasana kolegial. Dari hasil penelitian ditemukan hasil bahwa Guru yang mendapat perlakuan supervi klinis dapat meningkatkan kompetensinya dalam mengimplementasikan pendekatan saintifik pada pembelajaran.

Perlakuan supervisi klinis dengan nilai 66 dapat meningkatkan kompetensi guru sebesar $26 \%$, yaitu dari nilai 41 menjadi 67 pada siklus 1. Pada siklus 2 dibuat perbaikan dan penguatan perlakuan supervisi klinis hingga mencapai nilai 82 . Dari perlakuan yang lebih baik itu dapat menghasilkan peningkatan kompetensi guru dalam mengimplementasikan pendekatan saintifik pada pembelajaran sebesar $17 \%$ atau menjadi 83. Jika diakumulasi, peningkatan kompetensi guru itu mencapai $43 \%$. Sedangkan aktivitas guru pada kegiatan supervisi klinis mencapai 82.

Berdasarkan hasil penelitian di atas, penulis merekomendasikan kepada supervisor baik yang menjabat sebagai kepala sekolah atau pengawas agar dapat melakukan kegiatan supervisi klinis ini dengan tepat sesuai prosedur, pendekatan, dan prinsip supervisi klinis dan dilakukan secara reguler agar guru yang disupervisi dapat memperbaiki dan meningkatkan kompetensinya secara signifikan dan berkelanjutan.

Berisi kesimpulan akhir yang diperoleh dan saran perbaikan yang dianggap perlu ataupun penelitian lanjutan yang relevan. Ditulis dalam bentuk paragraf secara ringkas dan jelas hasil penelitian kemudian jelaskan konsekuensi logis dalam pengembangan ilmu dan praktik pendidikan terutama pendidikan Islam anak usia dini.

\section{Daftar Pustaka}

Azhari, A. 2004. Supervisi Rencana Program Pembelajaran. Jakarta: Rian Putra.

Azizy, H. A. Q., et all. 2002. Modul dan Model Pelatihan Pengawas PENDAIS. Jakarta: Dir.Jen. Kelembagaan Agama Islam.

Azizy, H. A. Q., et all. 2004. Pedoman Pengembangan Administrasi dan Supervisi Pendidikan. Jakarta: Ditjen Kelembagaan Agama Islam.

Hasan, A. Yusuf et all, 2002, Pedoman Pengawasan Untuk Madrasah dan Sekolah Umum, Jakarta:CV Mekar Jaya.

Permendikbud nomor 103 tahun 2014 tentang standar proses

Permendikbud nomor 65 tahun 2013 tentang standar proses

Permendikbud nomor 81A tahun 2013 tentang Implementasi Kurikulum 
Thaib BR, H. M. Amin dan A. Subagio, 2005, Kepengawasan Pendidikan, Jakarta : Ditjen. Kelembagaan Agama Islam

Tim Dir.Jen Kelembagaan Agama Islam, 2004, Pedoman Pengembangan Profesi Kepengawasan dan Penyusunan Karya Tulis IImiah Bagi Pengawas, Jakarta : Ditjen. Kelembagaan Agama Islam

Tim Ditjen Baga Islam, 2003, Pedoman Pelaksanaan Supervisi Pendidikan Agama, Jakarta : Ditjen. Kelembagaan Agama Islam

Tim Ditjen Baga Islam, 2003, Profesionalisme Pengawas PENDAIS, Jakarta : Ditjen. Kelembagaan Agama Islam.

Tola, B., dan Zakaria, T. R. 2003. Standar Supervisi dan Evaluasi Pendidikan. Jakarta: Direktorat Madrasah dan PAI Pada Sekolah Umum. 